\title{
Risk factors for acute kidney injury in postoperative cardiac surgery
}

\author{
Fatores de risco para injúria renal aguda no pós-operatório de cirurgia cardíaca \\ Factores de riesgo de lesión renal aguda en el postoperatorio de cirugía cardíaca
}

Received: 01/29/2021 | Reviewed: 02/04/2021 | Accept: 02/09/2021 | Published: 02/18/2021

\author{
Mario Augusto Cray da Costa \\ ORCID: https://orcid.org/0000-0001-9377-9495 \\ Universidade Estadual de Ponta Grossa, Brazil \\ E-mail: drmarioaugusto@uol.com.br \\ Stella Kuchller \\ ORCID: https://orcid.org/0000-0002-4080-6063 \\ Universidade Estadual de Ponta Grossa, Brazil \\ E-mail: stellakuchler@yahoo.com.br \\ Vanessa Carolina Botta \\ ORCID: https://orcid.org/0000-0003-2489-841X \\ Universidade Estadual de Ponta Grossa, Brazil \\ E-mail: vanessabotta94@gmail.com \\ Adriana de Fátima Menegat Schuinski \\ ORCID: https://orcid.org/0000-0002-0772-6846 \\ Universidade Estadual de Ponta Grossa, Brazil \\ E-mail: adrimenegat2@gmail.com \\ Ana Carolina Mello Fontoura de Souza \\ ORCID: https://orcid.org/0000-0003-2324-1301 \\ Universidade Estadual de Ponta Grossa, Brazil \\ E-mail:acmfs00@gmail.com
}

\begin{abstract}
Objective: To evaluate the perioperative risk factors associated with postoperative AKI in patients undergoing cardiac surgery. Methodology: Between January 2011 and December 2017, we analyzed prospectively 544 patients, who were divided into two groups: patients with acute kidney injury associated with cardiac surgery (AKI-ACS) defined as an increase of $0.3 \mathrm{mg} / \mathrm{dL}$ or 1.5 times the baseline serum creatinine value and control group formed by patients without AKI-ACS. We compared patients and surgical variables using the chi-square test, Fisher's exact test, and mannWhitney test and logistic regression. Results: AKI-ACS occurred in $29.8 \%$ of the patients. In the univariate analysis, the following variables presented a statistically significant difference: male gender $(\mathrm{p}=0.0087)$, age $(\mathrm{p}<0.0001)$, body mass $(\mathrm{p}=0.035)$, BMI $(\mathrm{p}=0.001)$, thoracic aortic surgery $(\mathrm{p}=0.029)$, use of extracorporeal circulation $(\mathrm{p}=0.012), C P B$ time $(p=0.0001)$, aortic clamping time $(p=0.0029)$, use of vasoactive drugs in post-operative period $(p=0.017)$, preoperative kidney function $(\mathrm{p}<0.0001)$, presence of diabetes mellitus $(\mathrm{p}=0.008)$ and NYHA functional class $(\mathrm{p}=0.041)$. In the multivariate analysis, the following variables presented a statistical difference: male gender (OR 2.11), higher BMI (OR 2.11), worse preoperative renal function, demonstrated by creatinine clearance (OR 0.13), longer cardiopulmonary bypass (OR 1.008). Conclusion: The independent predictors for LRA-ACC were male gender, higher body mass index, worse preoperative renal function, and more complex surgeries associated with longer cardiopulmonary bypass.
\end{abstract}

Keywords: Thoracic surgery; Renal insufficiency; Postoperative period; Myocardial revascularization; Heart valve prosthesis implantation.

\section{Resumo}

Objetivo: Avaliar os fatores de risco perioperatórios associados à lesão renal aguda pós-operatória em pacientes submetidos à cirurgia cardíaca. Metodologia: Entre janeiro de 2011 a dezembro de 2017 foram analisados banco de dados de 544 pacientes, divididos em dois grupos: os pacientes sem (grupo controle) e com lesão renal aguda associada à cirurgia cardíaca (LRA-ACC) definida por um aumento de $0,3 \mathrm{mg} / \mathrm{dL}$ ou de 1,5 vezes do valor de creatinina sérica basal. Foram comparadas variáveis referentes aos pacientes e ao ato cirúrgico em análise univariada e multivariada. Resultados: LRA-ACC ocorreu em $29,8 \%$ dos pacientes. Em análise univariada as seguintes variáveis apresentaram diferença estatística: sexo masculino $(\mathrm{p}=0,0087)$, idade $(\mathrm{p}<0,0001)$, massa corpórea $(\mathrm{p}=0,035)$, índice de massa corpórea (IMC) $(\mathrm{p}<0,0001)$, cirurgias em aorta torácica $(\mathrm{p}=0,029)$, uso de circulação extracorpórea (CEC) $(\mathrm{p}=0,012)$, tempo de CEC $(\mathrm{p}=0,0001)$, tempo de clampeio aórtico $(\mathrm{p}=0,0029)$, utilização de drogas vasoativas no pósoperatório $(\mathrm{p}=0,017)$, função renal pré-operatória $(\mathrm{p}<0,0001)$, presença de diabetes melitus $(\mathrm{p}=0,008)$ e classe funcional NYHA $(\mathrm{p}=0,041)$. Em análise multivariada, as seguintes variáveis apresentaram diferença estatística: 
gênero masculino (O.R. 2,11), maior IMC (O.R. 2,11), pior função renal pré-operatória, demonstrada através do clearance de creatinina (O.R. 0,13), maior tempo de circulação extracorpórea (O.R. 1,008). Conclusão: Os preditores independentes para LRA-ACC foram o gênero masculino, maior índice de massa corporal, pior função renal préoperatória, e maior tempo de circulação extracorpórea.

Palavras chave: Cirurgia torácica; Insuficiência renal; Período pós-operatório; Revascularização miocárdica; Implante de prótese de valva cardíaca.

\begin{abstract}
Resumen
Objetivo: Evaluar los factores de riesgo perioperatorios asociados a la IRA postoperatoria en pacientes sometidos a cirugía cardíaca. Metodología: Entre enero de 2011 y diciembre de 2017, se analizaron prospectivamente 544 pacientes, que se dividieron en dos grupos: pacientes con lesión renal aguda asociada a cirugía cardíaca (AKI-ACS) definida como un aumento de $0,3 \mathrm{mg} / \mathrm{dL}$ o 1,5 veces el valor de creatinina sérica basal y grupo control formado por pacientes sin AKI-ACS. Se compararon los pacientes y las variables quirúrgicas mediante la prueba de chi-cuadrado, la prueba exacta de Fisher y la prueba de Mann-Whitney y la regresión logística. Resultados: 29,8\% de los pacientes presentaron IRA-ACS. En el análisis univariante, las siguientes variables presentaron una diferencia estadísticamente significativa: sexo masculino ( $\mathrm{p}=0,0087)$, edad $(\mathrm{p}<0,0001)$, masa corporal $(\mathrm{p}=0,035), \mathrm{IMC}(\mathrm{p}=0,001)$, cirugía aórtica torácica $(\mathrm{p}=0,029)$, uso de circulación extracorpórea $(\mathrm{p}=0.012)$, tiempo de $\mathrm{CEC}(\mathrm{p}=0,0001)$, tiempo de pinzamiento aórtico $(\mathrm{p}=0,0029)$, uso de fármacos vasoactivos en el postoperatorio $(\mathrm{p}=0,017)$, función renal preoperatoria $(\mathrm{p}<0,0001)$, presencia de diabetes mellitus $(\mathrm{p}=0,008)$ y clase funcional de la NYHA $(\mathrm{p}=0,041)$. En el análisis multivariante, las siguientes variables presentaron una diferencia estadística: sexo masculino (OR 2,11), mayor IMC (OR 2,11), peor función renal preoperatoria, demostrada por el aclaramiento de creatinina (OR 0,13), bypass cardiopulmonar más largo (OR 1,008). Conclusión: Los predictores independientes de LRA-ACC fueron el sexo masculino, el mayor índice de masa corporal, la peor función renal preoperatoria y las cirugías más complejas asociadas a un bypass cardiopulmonar más largo.
\end{abstract}

Palabras clave: Cirugía torácica; Insuficiencia renal; Periodo posoperatorio; Revascularización miocárdica; Implantación de prótesis de válvulas cardíacas.

\title{
1. Introduction
}

Each year about 2 million people undergo cardiac surgery and presents several types of complications due to complexity of cardiac procedures (Husain- Syed et al., 2018). The acute kidney injury (AKI) is the most prevalent complication after cardiac surgery (Kumada, Yoshitani, Shimabara \& Ohnishi, 2017). Acute kidney injury associated with cardiac surgery (AKI-ACS) has a variable incidence according to the criterion used to define it, reaching 5 to $42 \%$ of the patients, and 1 to $5 \%$ will require renal replacement therapy (Crosina et al., 2017). The development of AKI is associated with an increase in morbidity and mortality, leading to an increased risk of hospital infection and multiple organ dysfunction, increase in hospital costs, time of hospital stay, time of intensive care unit (Crosina et al., 2017; Mangano, Diamondstone, Ramsay, Aggarwal, Herskowitz \& Mangano, 1998).

AKI injury may be defined as an increase of $0.3 \mathrm{mg} / \mathrm{dL}$ in serum creatinine over a 48-hour interval; or an increase greater than or equal to 1.5 times the baseline serum creatinine of the patient, within 7 days; or a urinary output less than $0.5 \mathrm{ml} / \mathrm{kg} / \mathrm{h}$ for 6 hours (Kidney Disease, 2012). AKI-ACS can be classified as early, when it occurs within 7 days of the surgical procedure, or late, occurring in the period between 7 and 30 days of the intervention, since it has only association with the procedure (Hoste \& Vandenberghe, 2017).

The pathophysiology of AKI-ACS is associated with perioperative situations ranging from preoperative characteristics to trans and postoperative events. Among the factors prior to the procedure, we can mention the use of drugs and nephrotoxic substances and / or patient characteristics, such as age, presence of peripheral or cerebral cardiovascular alterations, obesity, diabetes mellitus (DM), systemic arterial hypertension (SAH), chronic pulmonary obstructive disease (COPD), among others. Among the intraoperative factors, we can mention renal hypo perfusion, use of cardiopulmonary bypass (CPB), oxidative stress generated by reperfusion and thrombus formation with possible renal micro embolisms by cardiac manipulation. Finally, in the post-surgical period, the occurrence of rhabdomyolysis, cardiovascular shock with the use 
of vasopressor drugs can lead to renal hypo perfusion and consequently acute tubular necrosis (Bellomo et al., 2018; Sato, Matsuzawa \& Eguchi, 1982).

The present study aims to evaluate perioperative risk factors associated with postoperative acute kidney injury in patients submitted to cardiac surgery.

\section{Methodology}

\subsection{Kind of Study}

We conducted an observational, prospective case-control study based on a prospectively constructed database that included patients undergoing cardiac surgery at Santa Casa de Misericórdia de Ponta Grossa/PR, Brazil, after approval by the research ethics committee of the Ponta Grossa State University, protocol number 2.623.980.

The aim of the study was analyze the risk factors associated with the development of postoperative AKI-ACS.

\subsection{Inclusion and Exclusion Criteria}

We included patients undergoing cardiac surgery from January 2011 to December 2017. We excluded those who died during surgery or in the immediate postoperative period, those who were undergoing dialysis, or those whose data were incomplete.

\subsection{Study Groups and Analyzed Variables}

We classified the patients into two groups: AKI-ACS group and control group (CG) according to the development or non-development of AKI-ACS. We used the definition from the KDIGO (kidney disease improving global outcome) to define $\mathrm{AKI}$, in which, one of the following criteria is necessary:

-Elevated serum creatinine by at least $0.3 \mathrm{mg} / \mathrm{dL}$ within 48 hours;

- Elevated serum creatinine by at least 1.5 times the baseline value within 7 days; or

- Urine output less than $0.5 \mathrm{~mL} / \mathrm{kg} / \mathrm{h}$ in 6 hours.

We included in the study the variables used by EuroSCORE II as described below:

a)Gender;

b)Age;

c) Preoperative renal function divided into four groups: (i) considered normal when creatinine clearance (CC) is greater than $85 \mathrm{~mL} / \mathrm{min}$, (ii) considered moderate when the $\mathrm{CC}$ is in the range of $85 \mathrm{~mL} / \mathrm{min}$ and $50 \mathrm{~mL} / \mathrm{min}$, (iii) severe dysfunction with CC less than $50 \mathrm{~mL} / \mathrm{min}$ and (iv) severe when the patient was under dialysis;

d) Insulin-dependent or non-insulin-dependent diabetes;

e) Extracardiac arteriopathy - one or more of the following:

- claudication

- carotid occlusion or $>50 \%$ stenosis

- amputation for arterial disease

- previous or planned intervention on the abdominal aorta, limb arteries or carotids.

f) Poor mobility - severe impairment of mobility secondary to musculoskeletal or neurological dysfunction.

g) Chronic lung disease - long time use of bronchodilators or steroids for lung disease

h) Previous cardiac surgery;

i) Active endocarditis - patient still on antibiotic treatment for endocarditis at time of surgery; 
j) Critical preoperative state: ventricular tachycardia or ventricular fibrillation or aborted sudden death, preoperative cardiac massage, preoperative ventilation before anaesthetic room, preoperative inotropes or intra-aortic balloon pump;

k) Functional class by the New York Heart Association (NYHA);

1) Presence of class IV angina;

m) Left ventricular function: (i) good, with ejection fraction greater than $50 \%$, (ii) moderate when ejection fraction between 31 and 50\%, (iii) poor, when between 21 and 30\% and (iv) a lot poor, with ejection fraction less than 20\%; n) Pulmonary hypertension, classified as moderate when pulmonary artery systolic pressure between 31 and $55 \mathrm{mmHg}$ and severe when greater than $55 \mathrm{mmHg}$;

o) Recent acute myocardial infarction ( $<90$ days of the procedure);

p) Urgency now four classes:

- elective : routine admission for operation.

- urgent: patients who have not been electively admitted for operation but who require intervention or surgery on the current admission for medical reasons. These patients cannot be sent home without a definitive procedure.

- emergency: operation before the beginning of the next working day after decision to operate.

- salvage: patients requiring cardiopulmonary resuscitation (external cardiac massage) en route to the operating theatre or prior to induction of anaesthesia. This does not include cardiopulmonary resuscitation following induction of anaesthesia

q) Approach to the thoracic aorta.

In addition to the EuroSCORE II variables, we added other potentially damaging factors to the kidney such as: the presence of systemic arterial hypertension, hypothyroidism, dyslipidemia, smoking, alcoholism, weight, aortic clamping use and CPB time, and vasoactive drug use in the surgical center or in the immediate postoperative period.

Patients were followed daily with their serum creatinine values.

\subsection{Statistical analysis}

We tested through statistical analysis the variables that were possible risk factors for AKI-ACS. Continuous variables were presented as median or mean and standard deviation, while categorical variables were expressed by absolute number and percentage. Continuous variables were tested for normality, and when they had a normal distribution they were evaluated by the student's T test and when not normal, we used the Mann-Whitney U test, while using the exact Fisher test or the chi-square test for the categorical variables.

We performed univariate logistic regressions to gauge how each risk factor behaved. To do so, the values considered normal transformed into dummy variables in order to avoid perfect multicollinearity. The stratification of risk factors was performed according to studies consulted (Grayson, Khater, Jackson \& Fox, 2003).

We performed multivariate logistic regression analysis in order to evaluate independents variables, in this model we included the following variables: age, gender, body mass index, creatinine clearance, presence of diabetes mellitus, grade 4 angina, NYHA functional class III or IV, CPB time, surgery involving the thoracic aorta and use of vasoactive drugs in the postoperative period. We selected these variables due to the presence of positive association with the dependent variable and the development of renal injury. The variables were verified through bivariate analyzes and those that presented interaction or collinearity between them were excluded.

We considered P values less than 0.05 as significant. We used MedCalc® 14.8.1 software for statistical tests. 


\section{Results}

We analyzed data from 617 patients and excluded 38 because of incomplete information, 19 due to immediate postoperative or intraoperative deaths, and 16 patients due to the presence of prior chronic renal disease on dialysis. We obtained a final sample of 544 patients with mean age of 59.63 years, 346 men $(63.6 \%)$ and 198 women (36.4\%). The mean serum creatinine was $1.070 \mathrm{md} / \mathrm{dL}$. The incidence of acute renal injury in each type of surgery is shown in Table 1.

Table 1. Surgeries performed and AKI.

\begin{tabular}{lll}
\hline \multicolumn{1}{c}{ CABG } & N & AKI: N (\%) \\
$\quad$ On pump & & \\
$\quad$ Off pump & 213 & $76(35.7)$ \\
Valve repair or replacement & 116 & $25(21.5)$ \\
CABG + Valve repair or replacement & 142 & $37(26.0)$ \\
Asceding aortic surgery & 28 & $11(39.3)$ \\
Congenital anomalies (ASD, VSD, patent foramem ovale) & 15 & $6(40.0)$ \\
CABG + LV aneurismectomy & 6 & $4(26.6)$ \\
CABG + Asceding aortic surgery & 5 & $1(16.6)$ \\
Atrial tumor & 3 & $2(40.0)$ \\
LV aneurismectomy & 1 & $0(0)$ \\
\hline Total & 544 & $0(0)$ \\
\hline
\end{tabular}

AKI: acute kidney injury; ASD: atrial septal defect; CABG: coronary artery by-pass graft; LV: left ventricle; VSD: ventricular septal defect. Source: Authors.

162 patients (29.77\%) developed some degree of acute renal injury, while $382(70.59 \%)$ maintained their renal function preserved. In the group that evolved with renal injury, there was a prevalence of more than $70 \%$ of men, with a mean age of 63.4 years, the majority of patients had normal preoperative renal function or moderate dysfunction, with a mean serum creatinine of $1,18 \mathrm{mg} / \mathrm{dL}$ and clearance around $72 \mathrm{~mL} / \mathrm{min}$. There was a large predominance of surgeries with $\mathrm{CPB}(84.6 \%)$. When we considered only 329 patients who underwent CABP, CPB was used in 213 procedures (64.7\%), and of these 76 $(35.7 \%)$ developed AKI and 137 (64.3\%) did not. Among the 116 patients who did not need CPB during surgery, 25 (21.5\%) developed AKI and $91(78.5 \%)$ did not $(\mathrm{p}=0.007)$.

The analyzed variables are shown in Table 2, the ones with statistical significance were: male gender ( $\mathrm{p}=0.035)$; older patients $(\mathrm{p}<0.0001)$; the patients with greater weight $(\mathrm{p}=0.03)$; with higher serum creatinine $(\mathrm{p}=0.001)$; as well as higher creatinine clearance $(\mathrm{p}=0.001)$ and consequently the worse renal function $(\mathrm{p}<0.0001)$; presence of diabetes mellitus ( $\mathrm{p}=0.006)$; grade 4 angina $(\mathrm{p}=0.029)$; higher NYHA functional class $(\mathrm{p}=0.032)$; procedures involving ascending aorta $(\mathrm{p}=0.017)$; use of CPB ( $\mathrm{p}=0.01)$ and CPB time $(\mathrm{p}=0.0001)$; aortic clamping time $(\mathrm{p}=0.002)$; critical ill patients $(\mathrm{p}=0.0039)$; the use of postoperative vasoactive drugs $(\mathrm{p}=0.04)$ and the highest value of EuroSCORE II $(\mathrm{p}<0.0001)$. 
Table 2. Statistical analysis of risk factors to AKI-ACS using Fisher exact test, qui-square and U-mannwhitney.

\begin{tabular}{|c|c|c|c|c|}
\hline & $\begin{array}{l}\text { Total } \\
(n=544)(\%)\end{array}$ & $\begin{array}{l}\begin{array}{l}\text { No AKI-ACS } \\
(n=382)(\%)\end{array} \\
\end{array}$ & $\begin{array}{l}\text { AKI-ACS } \\
(n=162)(\%)\end{array}$ & $\boldsymbol{P}$ \\
\hline \multicolumn{5}{|l|}{ Gender } \\
\hline Male & $346(63.6)$ & $229(59.9)$ & $117(72.2)$ & \\
\hline Female & $198(36.4)$ & $153(40.1)$ & $45(27.8)$ & 0.0087 \\
\hline Age (years) & $59.63 \pm 12.22$ & $58.02 \pm 12.19$ & $63.42 \pm 11.47$ & $<0.0001$ \\
\hline Weigth (kilograms) & $75.34 \pm 15.05$ & $74.44 \pm 14.50$ & $77.87 \pm 16.28$ & 0.035 \\
\hline Body mass index & $26.88 \pm 5.08$ & $26.34 \pm 4.80$ & $28.68 \pm 5.59$ & $<0.0001$ \\
\hline Preoperative creatinine & $1.070 \pm 0.373$ & $1.022 \pm 0.248$ & $1.185 \pm 0.551$ & 0.0012 \\
\hline Creatinine Clearance & $79.15 \pm 27.04$ & $81.61 \pm 26.91$ & $72.23 \pm 26.29$ & 0.0013 \\
\hline \multicolumn{5}{|l|}{ Renal impairment } \\
\hline Normal & $214(39.3)$ & $161(42.1)$ & $53(32.7)$ & \\
\hline Moderate & $268(49.2)$ & $184(48.2)$ & $84(51.8)$ & \\
\hline Severe & $62(11.4)$ & $37(9.7)$ & $25(15.4)$ & $<0.0001$ \\
\hline Diabetes mellitus & $148(27.2)$ & $91(23.8)$ & $57(35.2)$ & 0.0088 \\
\hline Extracardiac arteriopathy & $117(21.5)$ & $74(19.4)$ & $43(26.5)$ & 0.08 \\
\hline Poor mobility & $7(1.3)$ & $4(1.0)$ & $3(1.8)$ & 0.446 \\
\hline COPD & $101(18.5)$ & $71(18.6)$ & $30(18.5)$ & 0.918 \\
\hline Previous cardiac surgegy & $41(7.5)$ & $26(6.8)$ & $15(9.2)$ & 0.415 \\
\hline Infectious endocarditis & $4(0.7)$ & $3(0.7)$ & $1(0.6)$ & 0.734 \\
\hline Critical ill patient & $6(1.1)$ & $1(0.2)$ & $5(3.1)$ & 0.015 \\
\hline \multicolumn{5}{|l|}{ NYHA class } \\
\hline I e II & $198(36.4)$ & $150(39.2)$ & $48(29.9)$ & \\
\hline III e IV & $346(63.6)$ & $232(60.7)$ & $114(70.1)$ & 0.041 \\
\hline Class IV angina & $137(25.2)$ & $86(22.5)$ & $51(31.5)$ & 0.036 \\
\hline \multicolumn{5}{|l|}{ Ejection Fraction } \\
\hline Good $(>50 \%)$ & $437(80.3)$ & $309(80.9)$ & $128(79.0)$ & \\
\hline Moderate (31-50\%) & $89(16.3)$ & $62(16.2)$ & $27(16.6)$ & \\
\hline Poor $(21-30 \%)$ & $16(2.9)$ & $9(2.3)$ & $7(4.3)$ & \\
\hline Very poor $(<21 \%)$ & $1(0.2)$ & $1(0.2)$ & $0(0)$ & 0.572 \\
\hline \multicolumn{5}{|l|}{ Pulmonary hypertention } \\
\hline No (SPAP <31mmHg) & $468(86.0)$ & $334(87.4)$ & $134(82.7)$ & \\
\hline Moderate (SPAP 31- & $56(10.3)$ & $36(9.4)$ & $20(12.3)$ & \\
\hline \multicolumn{5}{|l|}{$55 \mathrm{mmHg})$} \\
\hline Severe (SPAP & $20(3.7)$ & $12(3.1)$ & $8(4.9)$ & 0.326 \\
\hline \multicolumn{5}{|l|}{$>55 \mathrm{mmHg})$} \\
\hline Recente AMI & $123(22.6)$ & $78(20.4)$ & $45(27.8)$ & 0.077 \\
\hline \multicolumn{5}{|l|}{ Urgency } \\
\hline Elective & $464(85.3)$ & $329(86.1)$ & $135(83.3)$ & \\
\hline Urgent & $72(13.2)$ & $49(12.8)$ & $23(14.2)$ & \\
\hline Emergency & $8(1.5)$ & $4(1.0)$ & $4(2.4)$ & 0.400 \\
\hline Thoracic aortic surgery & $36(6.6)$ & $19(5.0)$ & $17(10.5)$ & 0.029 \\
\hline EuroSCORE II & $4.238 \pm 7.378$ & $3.299 \pm 4.505$ & $6.430 \pm 11.332$ & $<0.0001$ \\
\hline On pump surgery & $422(77.6)$ & $285(74.6)$ & $137(84.6)$ & 0.012 \\
\hline CPB time & $72.43 \pm 50.72$ & $66.97 \pm 48.75$ & $85.20 \pm 53.05$ & 0.0001 \\
\hline Aortic clamp time & $53.20 \pm 38.80$ & $49.43 \pm 36.75$ & $62.04 \pm 42.03$ & 0.0029 \\
\hline Hypothyroidism & $32(5.9)$ & $25(6.7)$ & $7(4.3)$ & 0.313 \\
\hline Arterial hypertention & $499(73.3)$ & $271(71.0)$ & $128(79.0)$ & 0.066 \\
\hline Smoking & $215(39.5)$ & $143(37.4)$ & $72(44.4)$ & 0.151 \\
\hline Alcoholism & $63(11.6)$ & $45(11.8)$ & $18(11.1)$ & 0.939 \\
\hline Dyslipidemia & $253(46.5)$ & $181(47.4)$ & $72(44.4)$ & 0.544 \\
\hline $\begin{array}{l}\text { Vasoactive drugs during } \\
\text { surgery }\end{array}$ & $232(42.6)$ & $169(44.2)$ & $63(38.9)$ & 0.289 \\
\hline Posoperative vasoactive drugs & $130(23.9)$ & $80(20.9)$ & $50(30.8)$ & 0.017 \\
\hline
\end{tabular}

AMI: acute myocardial infarction; AKI-ACS: acute kidney injury after cardiac surgery; COPD: chronic pulmonary obstructive disease; CPB: cardiopulmonary by-pass; SAPP: systolic pulmonary artery pressure. Source: Authors. 
Table 3 shows the results of the univariate analysis through logistic regression. Table 4 shows the multivariate analysis, where we can find the following results: male gender ( $\mathrm{p}=0.007$, OR 2.11, 95\% CI 1.218-3.661), BMI ( $\mathrm{p}<0.001$, OR 1.29, 95\% CI, creatinine clearance $(\mathrm{P}=0.0001, \mathrm{OR} 0.97,95 \%$ CI $0.960-0.986)$ and CPB time $(\mathrm{p}=0.003$, OR $1.008,95 \%$ CI $1.002-1.013)$ are risk factors for the development of AKI-ACS.

Table 3. Univariated logistic regression including risk factors to AKI- ACS.

\begin{tabular}{|c|c|c|c|c|c|c|}
\hline & Total & AKI-ACS & OR & CI 95\% & & $\boldsymbol{P}$ \\
\hline \multicolumn{7}{|l|}{ Gênero } \\
\hline Male & $63.6 \%$ & $72.2 \%$ & & & & \\
\hline Female & $36.4 \%$ & $27.8 \%$ & 0.57 & 0.38 & 0.85 & 0.006 \\
\hline \multicolumn{7}{|l|}{ Age (years) } \\
\hline$<65$ & $60.5 \%$ & $47.0 \%$ & & & & \\
\hline $65-75$ & $31.6 \%$ & $39.0 \%$ & 2.09 & 1.39 & 3.12 & 0.0003 \\
\hline$>75$ & $7.9 \%$ & $14.0 \%$ & 3.94 & 2.05 & 7.56 & $<0.0001$ \\
\hline \multicolumn{7}{|l|}{ Body mass index } \\
\hline$<\mathbf{3 0}$ & $76.3 \%$ & $65.9 \%$ & & & & \\
\hline $30-35$ & $16.6 \%$ & $20.7 \%$ & 1.56 & 0.97 & 2.51 & 0.06 \\
\hline$>35$ & $7.1 \%$ & $13.4 \%$ & 3.70 & 1.89 & 7.23 & 0.0001 \\
\hline \multicolumn{7}{|l|}{ Preoperative Creatinine } \\
\hline$<1.13 \mathrm{mg} / \mathrm{dL}$ & $63.4 \%$ & $50.1 \%$ & & & & \\
\hline $1.13-1.7 \mathrm{mg} / \mathrm{dL}$ & $32.9 \%$ & $40.2 \%$ & 1.86 & 1.25 & 2.75 & 0.002 \\
\hline$>1.7 \mathrm{mg} / \mathrm{dL}$ & $3.7 \%$ & $9.7 \%$ & 13.04 & 4.23 & 40.10 & $<0.0001$ \\
\hline \multicolumn{7}{|l|}{ Renal impairment } \\
\hline Normal & $40.1 \%$ & $32.7 \%$ & & & & \\
\hline Moderate & $49.2 \%$ & $51.8 \%$ & 1.36 & 0.91 & 2.03 & 0.13 \\
\hline Severe & $10.7 \%$ & $15.4 \%$ & 2.14 & 1.17 & 3.93 & 0.01 \\
\hline Diabetes melittus & $27.2 \%$ & $35.2 \%$ & 1.73 & 1.16 & 2.58 & 0.006 \\
\hline \multicolumn{7}{|l|}{ NYHA classe } \\
\hline $\mathbf{I}$ & $7.8 \%$ & $4.1 \%$ & & & & \\
\hline II & $28.5 \%$ & $25.2 \%$ & 1.37 & 0.51 & 3.65 & 0.52 \\
\hline III & $55.7 \%$ & $58.1 \%$ & 1.85 & 0.73 & 4.65 & 0.19 \\
\hline IV & $8.0 \%$ & $12.6 \%$ & 3.62 & 1.20 & 10.94 & 0.02 \\
\hline Angina class IV & $26.6 \%$ & $31.5 \%$ & 1.31 & 0.91 & 1.89 & 0.13 \\
\hline \multicolumn{7}{|l|}{ Ejection Fraction } \\
\hline Good $(>50 \%)$ & $80.5 \%$ & $79.0 \%$ & & & & \\
\hline Moderate(31-50\%) & $16.2 \%$ & $16.6 \%$ & 1.01 & 0.61 & 1.66 & 0.97 \\
\hline Poor $(21-30 \%)$ & $3.1 \%$ & $4.3 \%$ & 2.14 & 0.81 & 5,66 & 0.12 \\
\hline \multicolumn{7}{|l|}{ Urgency } \\
\hline Elective & $85.3 \%$ & $83.3 \%$ & & & & \\
\hline Urgent & $13.2 \%$ & $14.2 \%$ & 1.14 & 0.67 & 1.95 & 0.62 \\
\hline Emergency & $1.5 \%$ & $2.4 \%$ & 2.44 & 0.60 & 9.88 & 0.21 \\
\hline Thoracic aortic surgery & $6.6 \%$ & $10.5 \%$ & & & & 0.017 \\
\hline \multicolumn{7}{|l|}{ EuroSCORE II } \\
\hline Low $(\leq 2 \%)$ & $48.5 \%$ & $35.9 \%$ & & & & \\
\hline Moderate $(2-4 \%)$ & $25.5 \%$ & $29.3 \%$ & 1.83 & 1.16 & 2.89 & 0.009 \\
\hline Hight $(4-6 \%)$ & $8.5 \%$ & $9.7 \%$ & 1.77 & 0.89 & 3.52 & 0.1 \\
\hline Very hight $(>6 \%)$ & $17.5 \%$ & $25.1 \%$ & 2.69 & 1.63 & 4.44 & 0.0001 \\
\hline \multicolumn{7}{|l|}{ CPB time } \\
\hline$<90 \mathrm{~min}$ & $64.3 \%$ & $51.8 \%$ & & & & \\
\hline $90-180$ & $32.8 \%$ & $43.9 \%$ & 2.17 & 1.48 & 3.20 & 0.0001 \\
\hline$>180 \mathrm{~min}$ & $2.9 \%$ & $4.3 \%$ & 2.49 & 0.90 & 6.89 & 0.07 \\
\hline $\begin{array}{l}\text { Posoperative voactive } \\
\text { drugs }\end{array}$ & $22.9 \%$ & $30.8 \%$ & 1.74 & 1.15 & 2.64 & 0.009 \\
\hline
\end{tabular}

BMI: body mass index; CI: confidence interval; CPB: cardiopulmonary bypass; OR: odds ratio. Source: Authors. 
Table 4. Multivariated logistic regression including risk factors to AKI- ACS.

\begin{tabular}{llllll}
\hline & OR & IC 95\% & & P & Coeficient $\boldsymbol{\beta}$ \\
\hline Gender & & & & 0.007 & 0.7476 \\
Age & 2.112 & 1.218 & 3.661 & 0.552 & 0.0079 \\
BMI & 1.008 & 0.981 & 1.034 & $<0.0001$ & 0.2550 \\
Creatinine clearance & 1.290 & 1.186 & 1.404 & 0.0001 & -0.0271 \\
Diabetes mellitus & 0.973 & 0.960 & 0.986 & 0.198 & 0.3522 \\
NYHA Class III ou IV & 1.422 & 0.831 & 2.433 & 0.336 & 0.2635 \\
Classe IV Angina & 1.301 & 0.760 & 2.228 & 0.310 & 0.3037 \\
Thoracic aortic surgery & 1.354 & 0.753 & 2.436 & 0.386 & 0.5035 \\
CPB time & 1.654 & 0.529 & 5.171 & 0.003 & 0.0079 \\
Posoperative vasoactive & 1.008 & 1.002 & 1.013 & 0.171 & 0.3633 \\
drugs & 1.438 & 0.854 & 2.421 & & -8.0185 \\
Constant & & & & & -175 \\
\hline
\end{tabular}

BMI: body mass index; CI: confidence interval; CPB: cardiopulmonary bypass; OR: odds ratio. Source: Authors.

\section{Discussion}

In the present study, the incidence of acute kidney injury after cardiac surgery was $29.77 \%$, similar to the percentage found in two recent meta-analysis, both being 22\%, while another study conducted in Qatar resulted in 25\% (Hu et al., 2016; Vanderberghe et al., 2016; Hanoura et al., 2018). A recent study utilizing the KDIGO criterion, which was carried out in Brazil, demonstrated $22.17 \%$ of AKI-ACS in patients undergoing elective surgery on CBP (Goldani et al., 2019). We used the KDIGO criterion, which showed greater sensitivity when detecting AKI and predicting in-hospital mortality, compared to the AKIN and RIFLE criteria (Luo et al., 2014), KDIGO thus became the most widely used consensus for the diagnosis of AKIACS (Wang \& Bellomo, 2017).

Our study sought to determine the impact of Euroscore II and its variables in addition to other potentially risky factors on the development of AKI-ACS. The increased Euroscore II was shown to be a risk factor for the development of acute kidney injury as demonstrated by Ortega-Loubon et al. (2018). However, not only Euroscore II, but many of its variables, also proved to be risk factors for AKI in univariate and or multivariate analysis.

In this study, the male gender was shown to be associated with a greater chance of progressing to AKI ( $p=0.007$; OR $2.11 ; 95 \%$ CI 1.21 to 3.66), which is in agreement with four articles that used the AKIN criterion (Neugarten, Sandilya, Singh \& Golestaneh, 2016). There are still controversies about the role of gender in kidney injury. Even though the hormonal effect protects women from the development of ischemic kidney injury with a lower incidence of AKI after non-cardiac surgery, previous studies showed the female gender as a risk factor for AKI in cardiothoracic surgery. In order to clarify these controversies, Neugarten et al. conducted a systematic review and meta-analysis, including 64 studies and 1,057,412 individuals demonstrating that in univariate analysis there was a higher incidence of AKI-ACS (O.R. 1,2); however when the authors analyzed 120,464 individuals in 29 studies using the Acute Kidney Injury Network, RIFLE criteria, or the Kidney Disease Improving Global Outcomes criteria, there was no difference between the sexes. On the other hand, when the analysis was restricted to 5,016 patients in 4 studies that used the AKIN criterion, the risk of AKI was higher in men (O.R., 0.75; 95\% CI, 0.65 - 0.87; P <0.001) (Neugarten, Sandilya, Singh \& Golestaneh, 2016).

Still considering the demographic factors, age was related to a greater development of renal lesion $(\mathrm{p}<0.0001)$, patients with ages greater than 65 and 75 years presented an increased risk of AKI-RA in univariate logistic regression, however, age as continuous variable did not appear as an independent risk factor $(\mathrm{p}=0.552, \mathrm{OR} 1.008,95 \% \mathrm{CI} 0.981$ to 1.034). It is well understood that, with advancing age, there is a decrease in the renal capacity to adapt to the aggressions as hemodynamic changes that cause a lower renal plasma flow, either by low cardiac output or by the use of vasodilator drugs 
(Park, 2017). In addition, older patients are more subject to the use of nephrotoxic drugs and radiological contrasts, thus causing a negative effect on renal function (Park, 2017).

With the years of life, the prevalence of comorbidities increases, such as diabetes mellitus and the most frequent complication associated to DM is the nephropathy that is the main cause of chronic kidney disease in the world, and the second cause in Brazil. Therefore, diabetic patients have a greater tendency to develop renal injury, even without clinical or laboratory evidence of nephropathy (Kumada et al., 2017). Previous studies have suggested that DM is a risk factor for AKI-RA. Hertzberg et al., through a large observational study, evidenced the fact that the presence of type 1 DM significantly increased the incidence of renal injury after coronary surgeries (OR 4.89, CI 3.82-6.25), the same was observed with type 2 DM patients (OR 1.27, 95\% CI 1.16-1.40), although comparatively lower than type 1, regardless of prior renal function (Hertzberg, Sartipy \& Holzmann, 2015). In the present sample, the presence of DM was related to acute renal injury $(\mathrm{p}=0.006)$ in univariate analysis, but not in the multivariate analysis ( $\mathrm{p}=0.198$, OR $1.42,95 \%$ CI 0.831 to 2.433 ).

Systemic arterial hypertension is also a known cause of chronic kidney injury, and it is considered the main risk factor in our country (Luo et al., 2014). In the present study, it did not behave as such ( $\mathrm{p}=0.066$ ). The vast majority of patients included in the study had SAH, and in absolute numbers there was a higher incidence of AKI in the hypertensive group, but without statistical difference. An increase in the sample could confirm SAH as a risk factor for AKI. The same was observed with the presence of pulmonary hypertension, recent AMI, smoking and reoperation in which there was a difference in absolute numbers but without statistical difference. Reoperation can increase the risk of AKI by increasing the duration of CPB and increasing the risk of bleeding with hypotension and low renal perfusion. It is noteworthy that in all patients undergoing reoperation, our team performs as much of the adhesions dissection as possible before $\mathrm{CPB}$, in order to reduce $\mathrm{CPB}$ time and the risk of kidney injury. Even careful hemostasis reduces the risk of bleeding and hypotension. There was no difference regarding the presence of infectious endocarditis and peripheral arteriopathy, however the number of cases was too small in the sample to have statistical power. There was no difference in relation to obstructive pulmonary disease, although they may appear as risk factors in other studies (Rodrigues et al., 2009; Yamauchi, Miyagawa, Yoshikawa, Toda \& Sawa, 2017).

Overweight and obesity, analyzed by absolute weight $(\mathrm{p}=0.035)$ and BMI $(\mathrm{p}<0.0001)$ were statistically significant in univariate analysis, and the latter was an independent risk factor for outcome in multivariate analysis ( $<<0.0001$; OR 1.29, 95\% CI 1.18 to 1.40) According to Zou et al.(2018) a 5-point increase in body mass index at admission led to a 5.8\% increase in the risk adjusted for the development of AKI-ACC. The pathophysiological mechanism is possibly related to insulin resistance and hyperinsulinemia of the obese patient, which leads to inadequate activation of the renin-angiotensin-aldosterone system and increased oxidative stress in the kidneys due to the effect of hormonal secretion and the release of inflammatory cytokines. In addition, obese patients have increased renal plasma flow and glomerular filtration, which promotes glomerular capillary hypertension, leading to structural changes in the kidneys (Zou et al., 2018).

The renal function prior to the surgical procedure is directly related to the development of postoperative renal damage, either through the serum creatinine concentration $(\mathrm{p}=0.0012)$ or the clearance estimated by the Cockroft-Gault formula $(\mathrm{p}=$ 0.0001; OR 0.97, 95\% CI 0.96 to 0.98) or stratification of renal function ( $\mathrm{p}<0.0001$ ) (Hanoura et al., 2018). Undoubtedly, the presence of previous renal impairment should be one of the surgeon's main concerns, since it is a high-risk group for worsening renal function in the perioperative period. Abundant hydration strategy, maintaining adequate pressure and parsimonious use of vasoactive drugs can minimize kidney damage. It should be noted that, if hypotension is harmful on the one hand, the use of high doses of vasoconstrictor drugs can also be harmful. Optimizing the preload and afterload can help the intensivist to minimize the use of vasoconstrictor drugs and reduce kidney injury. The use of loop diuretics can be useful when the preload is optimized and the urine output is low. 
In addition to the factors intrinsic to the patient, it is known that the use of CPB may predispose to renal injury, once a state of systemic inflammation is formed and the development of pro-inflammatory events that amplify the operative trauma occurs, as well as to the microembolism that come from the procedure (McGuinness, Bouchier-Hayes \& Redmond, 2008; Thiele, Isbell \& Rosner, 2015). Conlon et al. (1999), through a cohort study with a sample of 2843, demonstrated the increased incidence of renal damage associated with CPB and its time of use. In the current study, these results were confirmed $(\mathrm{p}=$ 0.003; OR 1.008; 95\% CI 1.002 to 1.013). Strategies to reduce CPB time are always welcome. For instance, our team routinely optimizes CPB time in coronary surgeries. The no-touch vein dissection technique is used with the anastomoses of the veins in the aorta made with lateral clamping, before entering the CPB. This technique has a double benefit: the veins are dilated by pressure in the aorta, which minimizes the endothelial damage to the veins and there is also a reduction in the time of extracorporeal circulation.

Aortic clamping time and type of surgery were also correlated with this complication. Wu et al. (2018) found an incidence of LRA-ACS in 57\% of patients undergoing tricuspid annuloplasty. The association of two cardiac procedures or the intraoperative approach of the thoracic aorta caused a higher incidence of renal injury, presumably due to the greater complexity of the surgery and operative time (Mangano et al., 1998). In the present sample, the occurrence of AKI was noted in $40 \%$ of the surgeries involving the thoracic aorta and $39.3 \%$ of those who associated revascularization with a valve approach.

The use of vasopressor drugs to control hemodynamic instability can lead to a decrease in renal blood flow, a condition observed mainly with the use of noradrenaline and adrenaline and less pronounced with dobutamine (Sato, Matsuzawa \& Eguchi, 1982). Dopamine does not exhibit such a decrease in flow, including improved renal hemodynamics, especially if applied in low doses (Sato, Matsuzawa \& Eguchi, 1982), an effect also observed by Hanoura et al. (2018) and contrary to a study recently published by Ramos \& Dias, 2018. In our study, the use of such drugs in the surgical center did not show statistical significance, whereas postoperative use was significant $(\mathrm{p}=0.04)$, but not as an independent risk factor $(\mathrm{p}$ $=0.17$; OR $1.43 ; 95 \%$ CI 0.85 to 2.42 ).

Finally, the association between the development of AKI and the increase in mortality within 30 days can be observed (Mizuguchi et al., 2018). In addition, several studies have found a high risk of progression from acute renal injury to chronic kidney disease, which justifies the rigorous monitoring of the renal function of these patients (Wang \& Bellomo, 2017). As this work occurred in a transverse and retrospective way, there was no follow-up, therefore it was impossible to corroborate these hypotheses.

The present study presents some limitations that must be emphasized: despite a relatively large sample, it is a single center study. The variables were collected in a database.

\section{Conclusion}

In the present study, in the univariate analysis, the male gender, older age, greater weight and higher BMI, worse preoperative renal function, presence of diabetes, class IV angina, critically ill patients, more complex surgeries, longer CPB and aortic clamping time, use of vasoactive drugs in the postoperative period presented a higher incidence of acute renal injury after cardiac surgery; however, only the male gender, higher BMI, worse preoperative creatinine clearance and longer cardiopulmonary bypass showed as risk factors for acute renal injury in multivariate analysis. More work in the area is suggested to identify all the risk factors to this complication and, therefore, prevented it whenever possible. 


\section{References}

Bellomo R., Auriemma S., Fabbri A., D’Onofrio A., Katz N., Mccullough, P. A., \& Ronco C. (2018). The pathophysiology of cardiac surgery-associated acute kidney injury (CSA-AKI). The International Journal of Artificial Organ, 31(2), 166-178.

Conlon, P. J., Stafford-Smith, M., White, W. D., Newman, M. F., King S., Winn, M. P., \&. Landolfo, K. (1999). Acute renal failure following cardiac surgery. Nephrol Dial., 14(5), 1158-62.

Crosina J., Lerner J., Ho J., Tangri N., Komenda P., Hiebert B. \& Rigatto C. (2017). Improving the prediction of cardiac surgery-associated acute kidney injury. Kidney Int Rep, 2(2), 172-179

Goldani J. C., Poloni J. A., Klaus F., Kist R., Pacheco L. S., \& Keitel E. (2019). Microscopia urinária como biomarcador de lesão renal aguda após cirurgia cardíaca com circulação extracorpórea. J. Bras. Nefrol., 42 (1), 18-23.

Grayson A. D., Khater M., Jackson M. \& Fox M. A. (2003). Valvular heart operation is an independent risk factor for acute renal failure. The annals of Thoracic Surgery, 75(6), 1829-1835.

Hanoura S., Omar AS., Osman H., Sudarsanan S., Eissa M., Maksoud M. \& Khulaifi A.A. (2018). Prevalence and predictors of acute kidney injury after cardiac surgery: a single-centre retrospective study in Qatar. Netherlands Journal of Critical Care, 26(1), 14-19.

Hertzberg D., Sartipy U. \& Holzmann M. J. (2015). Type 1 and type 2 diabetes mellitus and risk of acute kidney injury after coronary artery bypass grafting. Am Heart J. 170(5), 895-902.

Hoste E. A. \& Vandenberghe W. (2017). Epidemiology of cardiac surgery associated acute kidney injury. Best Practice \& Research Clinical Anaesthesiology, 31(3), 299-303.

Hu J., Chen R., Liu S., Yu X., Zou J. \& Ding X. (2016). Global incidence and outcomes of adult patients with acute kidney injury after cardiac surgery: A systematic review and meta-analysis. J Cardiothorac Vasc Anesth, 30, 82-89.

Husain-Syed F., Ferrari F., Sharma A., Hinna Danesi T., Bezerra P., LopezGiacoman S. \& Ronco C. (2018). Preoperative renal functional reserve predicts risk of acute kidney injury after cardiac surgery. The Annals of Thoracic Surgery, 105 (4), 1094-1101.

Kidney Disease (2012). Improving Global Outcomes (KDIGO) acute kidney injury work group. KDIGO Clinical Practice Guideline for Acute Kidney Injury. Kidney Int, Suppl 2, 1-138.

Kumada Y., Yoshitani K., Shimabara Y. \& Ohnishi Y. (2017). Perioperative risk factors for acute kidney injury after off-pump coronary artery bypass grafting: a retrospective study. JA Clin Rep, 3(1).

Luo X., Jiang L., Du B., Wen Y., Wang M. \& Xi X. (2014). A comparison of different diagnostic criteria of acute kidney injury in critically ill patients. Crit. Care, 18(4).

Mangano C. M., Diamondstone L. S., Ramsay J. G., Aggarwal A., Herskowitz A \& Mangano D.T. (1998). Renal dysfunction after myocardial revascularization: Risk factors, adverse outcomes, and hospital resource utilization. Ann Intern Med, 128, $194-203$.

McGuinness J., Bouchier-Hayes D. \& Redmond J. M. (2008). Understanding the inflammatory response to cardiac surgery. Surgeon, 6(3), 162-71.

Mizuguchi A., Huang C. C., Shempp I., Wang J., Shekar P. \& Frendl G. (2018). Predicting kidney disease progression in patients with acute kidney injury after cardiac surgery. J Thorac Cardiovasc Surg., 155 (6), 2455-2463.

Neugarten J., Sandilya S., Singh B. \& Golestaneh L. (2016). Sex and the risk of AKI following cardio-thoracic surgery: A meta-analysis. Clin J Am Soc Nephrol, 11(12), 2113-2122.

Ortega-Loubon C., Fernández-Molina M., Pañeda-Delgado L., Jorge-Monjas P. \& Carrascal Y. (2018). Predictors of postoperative acute kidney injury after coronary artery bypass graft surgery. Braz J Cardiovasc Surg, 33(4), 323-9.

Park J. T. (2017). Postoperative acute kidney injury. Korean J Anesthesiol, 70(3), 258-266.

Ramos A.K. \& Dias C.B. (2018). Acute kidney injury after cardiac surgery in patients without chronic kidney disease. Braz J Cardiovasc Surg, 33(5),454-61.

Rodrigues A. J., Evora P. R. B., Bassetto S., Alves J. L., Scorzoni F.A., Araújo W. F.. \& Vicente W. V. A. (2009). Fatores de risco para lesão renal aguda após cirurgia cardíaca. Rev Bras Cir Cardiovasc, 24(4), 441-446.

Sato Y., Matsuzawa H. \& Eguchi S. (1982). Comparative study of effects of adrenaline, dobutamine and dopamine on systemic hemodynamics and renal blood flow in patients following open heart surgery. Japanese Circulation Journal, 46, 1059-1072.

Thiele R. H., Isbell J. M. \& Rosner M. H, (2015). AKI associated with cardiac surgery. Clin J Am Soc Nephrol, 10(3), 500-514.

Vandenberghe W., Gevaert S., Kellum J. A., Bagshaw S. M., Peperstraete H., Herck I. \& Hoste E.A.J. (2016). Acute kidney injury in cardiorenal syndrome type 1 patients: A systematic review and meta-analysis. Cardiorenal Med, 6, 116-128.

Wang Y. \& Bellomo R. (2017). Cardiac surgery-associated acute kidney injury: risk factors, pathophysiology and treatment. Nat Rev Nephrol., 13(11), 697711. 
Research, Society and Development, v. 10, n. 2, e34710212480, 2021

(CC BY 4.0) | ISSN 2525-3409 | DOI: http://dx.doi.org/10.33448/rsd-v10i2.12480

Wu M. Z., Chen Y., Au W.K., Chan D., Sit K. Y., Ho K. L. \& Yiu K. (2018). Predictive value of acute kidney injury for major adverse cardiovascular events following tricuspid annuloplasty: A comparison of three consensus criteria. J Cardiol. 72 (3), 247-254.

Yamauchi T., Miyagawa S., Yoshikawa Y., Toda K. \& Sawa Y. (2017). Risk index for postoperative acute kidney injury after valvular surgery using cardiopulmonary bypass. Ann Thorac Surg, 104(3), 868-875.

Zou Z., Zhuang Y., Liu L., Shen B., Xu J., Luo Z. \& Ding X. (2018). Role of body mass index in acute kidney injury patients after cardiac surgery. Cardiorenal Med, 8, 9-17. 